\title{
Archaeological Testing of 41BX1131 at O.R. Mitchell Dam, Bexar County, Texas
}

David L. Nickels

Center for Archaeological Research

Aric Kertis

Center for Archaeological Research

Follow this and additional works at: https://scholarworks.sfasu.edu/ita

Part of the American Material Culture Commons, Archaeological Anthropology Commons, Environmental Studies Commons, Other American Studies Commons, Other Arts and Humanities Commons, Other History of Art, Architecture, and Archaeology Commons, and the United States History Commons

Tell us how this article helped you.

This Article is brought to you for free and open access by the Center for Regional Heritage Research at SFA ScholarWorks. It has been accepted for inclusion in Index of Texas Archaeology: Open Access Gray Literature from the Lone Star State by an authorized editor of SFA ScholarWorks. For more information, please contact cdsscholarworks@sfasu.edu. 


\section{Archaeological Testing of 41BX1131 at O.R. Mitchell Dam, Bexar County, Texas}

Creative Commons License

(c) (i) (8)

This work is licensed under a Creative Commons Attribution-NonCommercial 4.0 International License 


\section{Archaeological Testing of 41BX1131 at O. R. Mitchell Dam, Bexar County, Texas}

David L. Nickels and Aric Kertis

Robert J. Hard and C. Britt Bousman

Principal Investigators

Ocopyright

Center for Archaeological Research

The University of Texas at San Antonio

Archaeological Survey Report, No. 232

1995 
The following information is provided in accordance with the General Rules of Practice and Procedure, Chapter 41.11 (Investigative Reports), Texas Antiquities Committee:

1. Type of Investigation: Survey and limited subsurface testing;

2. Project name: Mitchell Dam;

3. County: Bexar;

4. Principal investigator: Robert J. Hard; Co-Principal investigator: C. Britt Bousman;

5. Name and location of sponsoring agency: Simpson Group, 7073 San Pedro, San Antonio, Texas 782166280 ;

6. Texas Antiquities Permit No.: n/a;

7. Published by the Center for Archaeological Research, The University of Texas at San Antonio, San Antonio, Texas 78249-0658, 1995.

A list of publications offered by the Center for Archaeological Research is available. Call (210) $691-4378$ or write to the Center for Archaeological Research, The University of Texas at San Antonio, 6900 N. Loop 1604 West, San Antonio, Texas 78249-0658. 


\begin{abstract}
The Center for Archaeological Research contracted with the Simpson Group to conduct testing of 41BX1131, a prehistoric archaeological site located at the base of $\mathrm{O}$. R. Mitchell Dam, on

A pedestrian survey identified the extent of surface scatter. Subsequent shovel testing and backhoe trenching determined that the site had no depth, and consisted of a surface scatter only.
\end{abstract} Medio Creek in southwest Bexar County. The purpose of testing was to determine whether or not the site would be impacted by construction of a spillway in the immediate area. 


\section{CONTENTS}

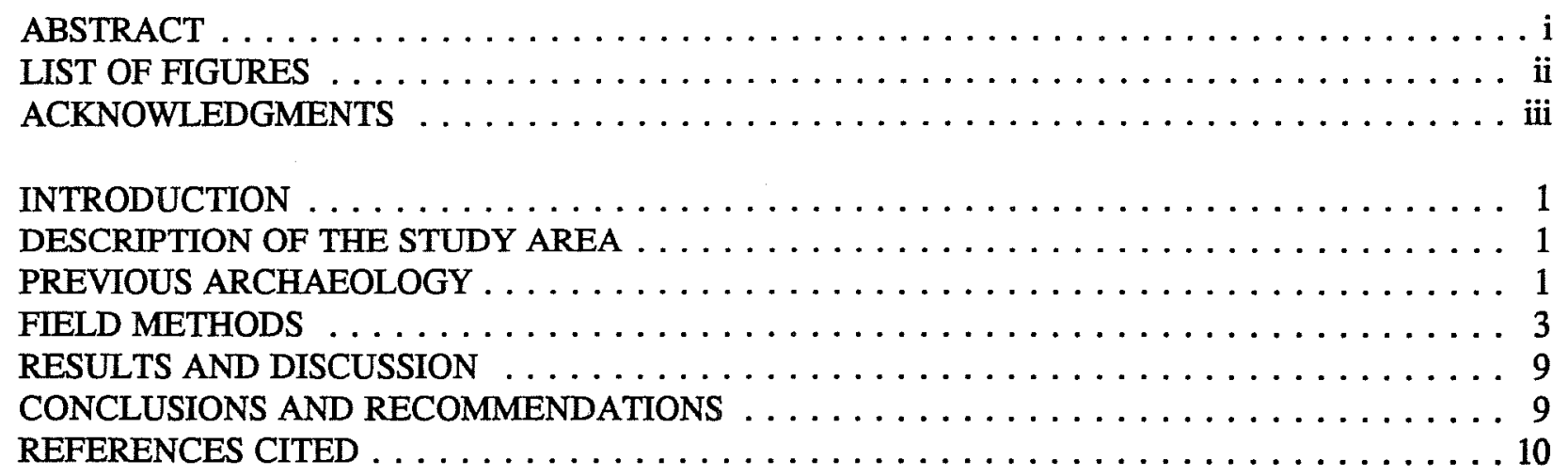

\section{FIGURES}

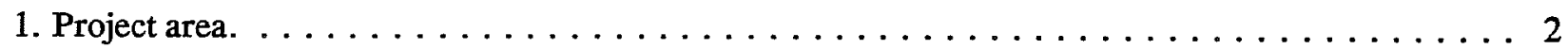

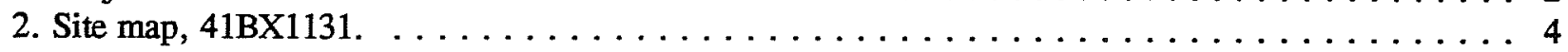

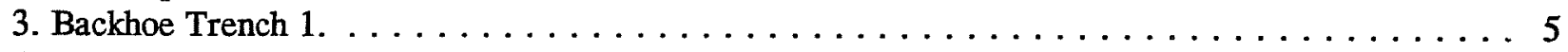

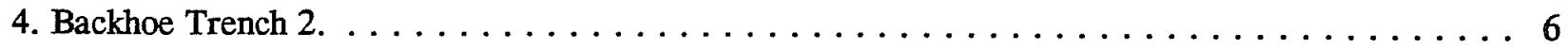

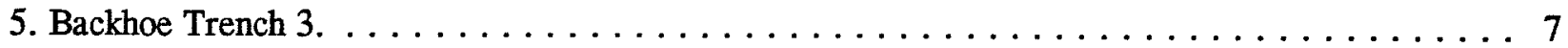

6. Backhoe Trench 4. . . . . . . . . . . . . . . . . . . 8 


\section{ACKNOWLEDGMENTS}

We would like to thank Mr. L. David Givler, senior project engineer with the Simpson Group, for his cooperation, expertise, and assistance throughout the project. A word of thanks also is expressed to $\mathrm{Mr}$. Todd Coston, land manager at Medio Creek Ranch, for allowing our crews access to the property.
The project could not have been completed without the fieldwork of UTSA interns Donna Edmondson, Connie Gibson, and Adrian Sapp. Marcie Renner's technical support as editor is appreciated. Dr. Robert J. Hard and Dr. C. Britt Bousman are thanked for providing professional advice and guidance throughout the project. 


\section{INTRODUCTION}

In May 1995, David Givler, acting on behalf of the Simpson Group, contracted with the Center for Archaeological Research (CAR) of The University of Texas at San Antonio to conduct limited testing to assess the integrity and potential significance of site 41BX1131. Planned construction of a concrete spillway over O. R. Mitchell Dam on Medio Creek, southwest Bexar County, Texas (Figure 1), will directly impact the site. The site is located on privately owned property; however, the waterway (Medio Creek) falls under the jurisdiction of the U.S. Army Corps of Engineers (COE). The site was recorded in March 1995 by Robert Scott, COE staff archaeologist. On June 20 and 27, 1995, CAR staff archaeologist David L. Nickels and four UTSA student interns conducted a pedestrian survey, systematically shovel tested, and documented backhoe trenches at the project area.

The approximately 65-x-75-m rectangular project area was bounded on the north by $O$. R. Mitchell Dam, on the west by Medio Creek, on the south by a line of mature trees and brush, and on the east by a plowed field (Figure 2). The project area was restricted in size to an area large enough to allow for construction of the spillway. The spillway impact area would actually cover about 85 percent of the project area (Figure 2). A pedestrian survey and subsurface testing determined that the site was limited to the eastern one-third of the project area. Most likely the site had extended farther north and was buried or removed during construction of the dam in the 1940 s. It probably extended into the tree line to the south; however, that area of private land was not within the project area and was not surveyed. Even though the plowed field surface on the east boundary of the site was not included in the project area, it was examined while walking back and forth to the vehicle. No artifacts were observed on the surface in that area.

\section{DESCRIPTION OF THE STUDY AREA}

41BX1131 is located on an eight-meter terrace on the east side of Medio Creek, adjacent to the south bank of O. R. Mitchell Dam. The site rests in Trinity clay, and Trinity and Frio soils. Both soil types lie on $0-1$ percent slopes, and because they occur most commonly on narrow, low-lying terraces, they frequently flood. Heavy rainfalls cause these soils to scour and erode, while lowenergy flood episodes deposit thin layers of sediment (Taylor et al. 1962:32). The geologic formation underneath is Edwards marl (Geologic Atlas of Texas 1974: San Antonio sheet), part of the Wilcox and Midway groups formed in the Lower Eocene period over 64 million years ago (Judson and Kauffman 1990:150). Until late 1994, when the land was cleared of all vegetation, the site was covered with a dense growth of honey mesquite (Prosopis glandulosa) and hackberry (Celtis laevigata), secondary brush, grasses, and weeds. At the time of the CAR survey, a dense growth of invasive weeds again covered the site. However, archaeological visibility was estimated at 70 percent across the entire project area, and 100 percent in the adjacent plowed field.

\section{PREVIOUS ARCHAEOLOGY}

The southern half of Bexar County (including 41BX1131) falls within the Nueces-Guadalupe Plain, a biogeographical subarea of the South Texas Plains. Southeasterly flowing streams and rivers provided strands of riparian vegetation attractive for occupation by prehistoric groups. These stream-side vegetation zones yielded highdensity food resources for exploitation. It is not surprising then that the Nueces-Guadalupe Plain contains a significant archaeological record (Black 1989:39-40). Examples of other archaeological sites in nearby riparian zones are the Quinta Medina (41BX53), Tschirhart (41ME70), River Bluff (41ME77), and Diversion (41ME8) sites; as well as sites at the Applewhite Reservoir project and Lackland Air Force Base. 


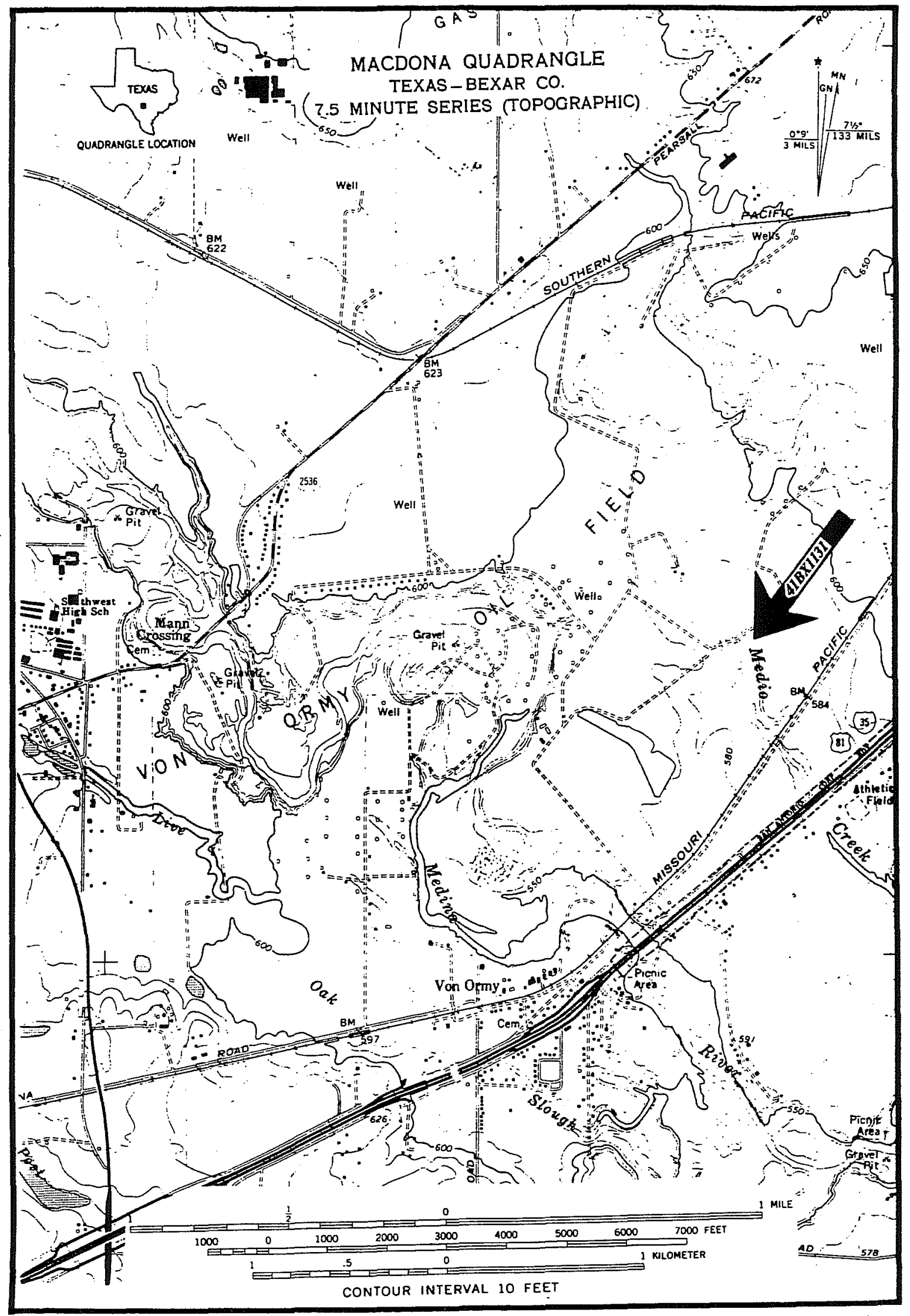

Figure 1. Project area. 
Quinta Medina, Tschirhart, River Bluff, and Diversion are $24 \mathrm{~km}$ to the west of the project area, along the Medina River. These sites have confirmed single- or multicomponent occupations from the Paleoindian through the Late Prehistoric periods (Guderjan et al. 1993:12-26). The complex of sites recorded in 1981 and 1984 (McGraw and Hindes 1987: 104-382) within the footprint of the proposed Applewhite Reservoir are within $11 \mathrm{~km}$ of 41BX1131. During the Applewhite Project, 59 prehistoric sites were identified or revisited within the riparian zone of Medina River. Those sites were used for habitation or manufacturing activities, and have been chronologically placed within the Paleoindian through Late Prehistoric periods. CAR staff archaeologists have recorded 26 prehistoric archaeological sites within the riparian zone adjacent to Medio Creek on Lackland Air Force Base, $5.6 \mathrm{~km}$ north of 41BX1131. Those sites are Early Archaic to Late Prehistoric open sites and lithic quarries (Nickels et al. 1995).

\section{FIELD METHODS}

The location of 41BX1131 provided an opportunity to obtain a cross-section view of the terrace with shovel tests and backhoe trenches. A 5-m-square grid pattern was superimposed across the project area using tape measures. Transects and stations were then marked with flagging tape and labeled with alpha-numeric characters (Figure 2). A pedestrian survey was conducted at 5-m intervals on transect lines. All surface artifacts were flagged to establish their density and distribution. Three light artifact concentrations were identified, with a sparse scatter of artifacts on the remainder of the site.

Once the survey was completed, the construction impact area was superimposed over the site boundary (Figure 2). In the impact area, 18 shovel tests were excavated in 10-cm levels to an arbitrary depth of $50 \mathrm{~cm}$. Shovel tests (ST) were initially conducted in a systematic $10-\mathrm{m}$ grid; however, as the procedure progressed from northeast to southwest and no cultural material was recovered, the testing interval was increased to 15 and $20 \mathrm{~m}$.
ST I-9 was the only one that produced cultural material. Two primary flakes and three fragments of firecracked rock were recovered from $42 \mathrm{~cm}$ below the surface. Two shovel tests (I-8 and I-10) were then excavated $5 \mathrm{~m}$ to either side of I-9; no cultural material was found. Four shovel tests were excavated outside of the impact area. ST C-3 was placed in the center of the single surface scatter outside of the direct impact area, in the interest of further determining the integrity of the site (Figure 2); no cultural material was found below the surface.

Four backhoe trenches (BHTs) were also dug (Figure 2). Each was positioned to expose a portion of the subsurface deposits over the impact area. BHTs were dug perpendicular to the creek bed to find depositional units and possible shifts in stream channel locations. The trenches were dug to an arbitrary length of $10 \mathrm{~m}$, except for BHT 4 which was $5 \mathrm{~m}$ in length (Figures 3-6). BHT 1 cut through the surface scatter concentration on the east edge of the site. BHT 2 was placed in the northwest corner of the impact area; although not associated with any defined cultural surface scatter, it could yield information on potential buried deposits. BHT 3 was positioned to further examine the area of ST I-9 which yielded cultural material. BHT 4 was placed in the southeast corner of the impact area; although not associated with a surface artifact concentration, its placement and depth were designed to confirm any possibilities of buried cultural material within the upper terrace deposits. All four BHTs were carefully monitored for cultural material. No cultural material was found in any of the BHTs, nor in their backdirt. The trench walls were profiled and photographed, and the BHTs backfilled. 
This page has been

redacted because it

contains restricted

information. 


\section{Backhoe Trench 1}
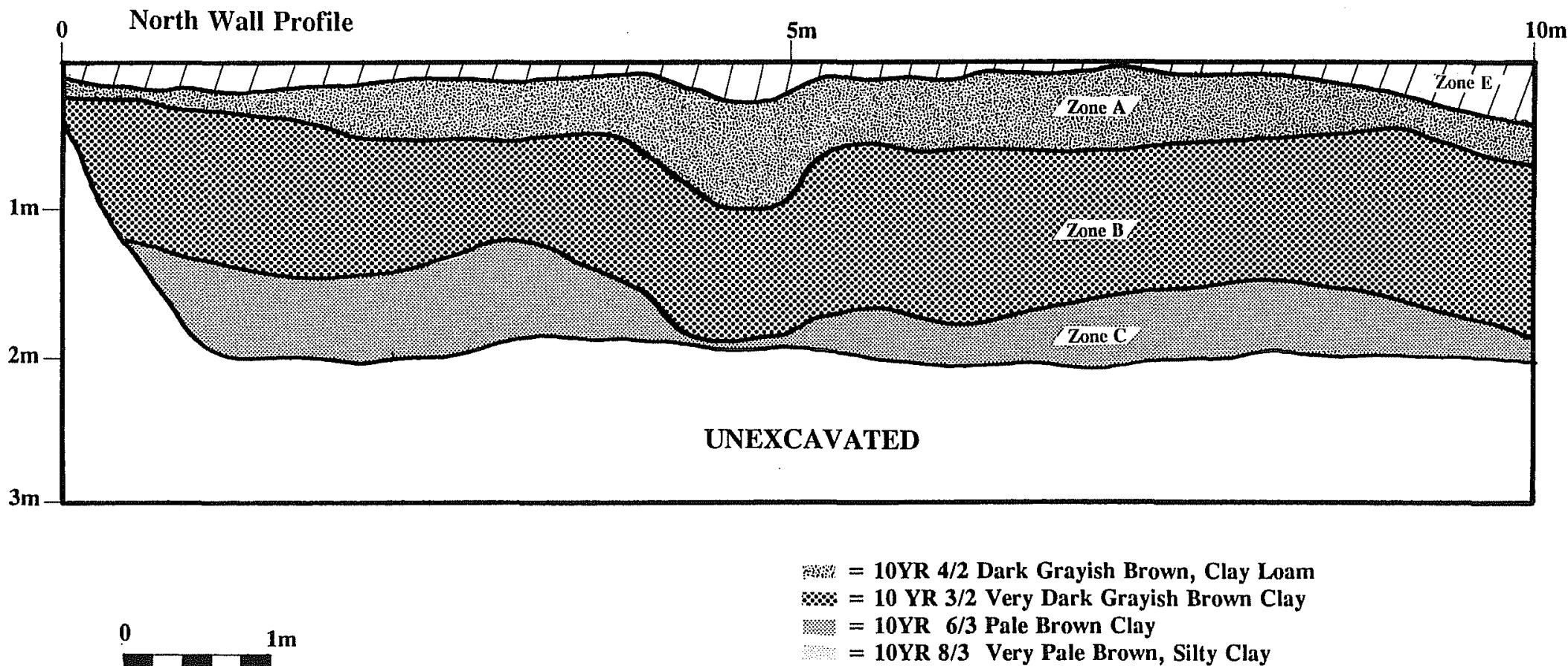

mat $=$ 10YR 4/2 Dark Grayish Brown, Clay Loam

\% $=10$ YR 3/2 Very Dark Grayish Brown Clay

\% $=10$ YR 6/3 Pale Brown Clay

10YR 8/3 Very Pale Brown, Silty Clay

$[\bar{I}=$ Construction Fill

Figure 3. Backhoe Trench 1. 


\section{Backhoe Trench 2}

a

\section{$0 \quad$ North Wall Profile}

$5 \mathrm{~m}$

$10 \mathrm{~m}$

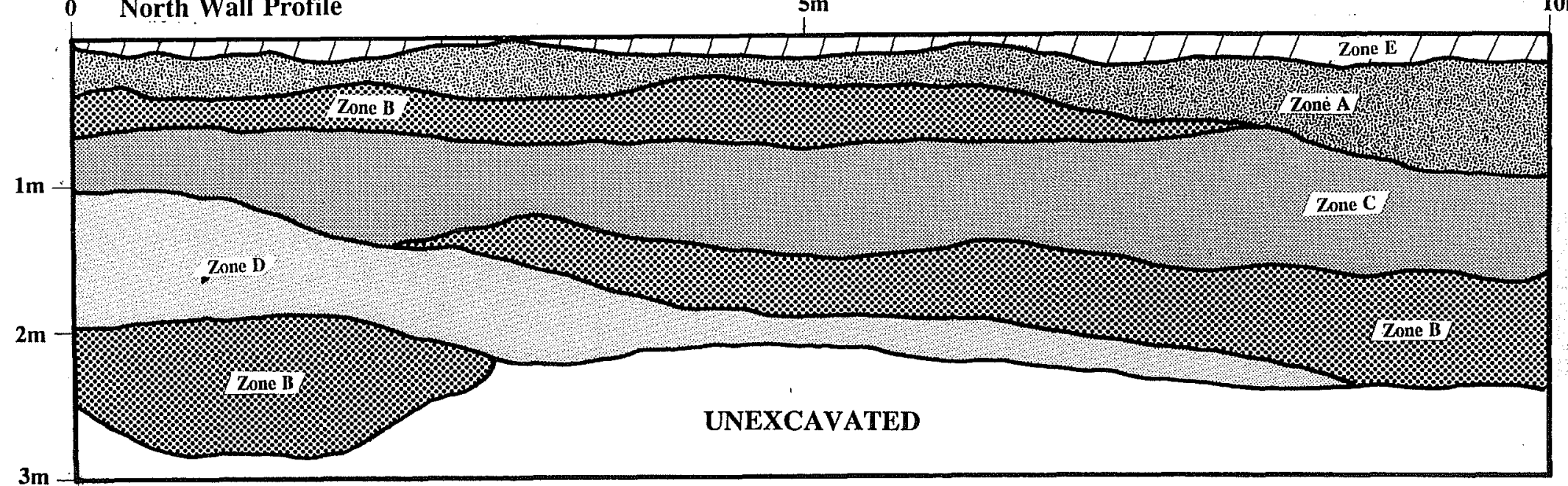

0 $1 \mathrm{~m}$

wat $=$ 10YR 4/2 Dark Grayish Brown, Clay Loam xo $=10$ YR 3/2 Very Dark Grayish Brown Clay

\%:\% 10YR 6/3 Pale Brown Clay

1⿴囗十

$=10$ YR 8/3 Very Pale Brown, Silty Clay

ZZl $=$ Construction Fill

Figure 4. Backhoe Trench 2 . 


\section{Backhoe Trench 3}

o North Wall Profile $5 \mathrm{~m}$

$10 \mathrm{~m}$

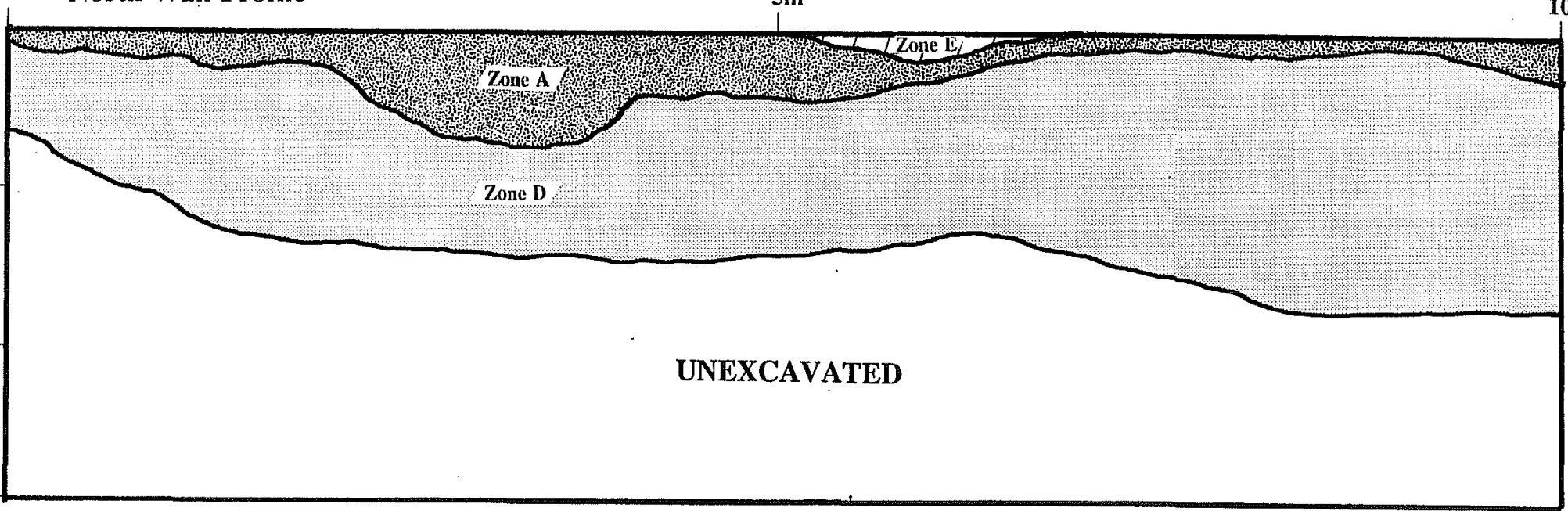

0

$1 \mathrm{~m}$

W $=$ 10YR 4/2 Dark Grayish Brown, Clay Loam

\% $\%=10$ YR 3/2 Very Dark Grayish Brown Clay

w: $=$ 10YR 6/3 Pale Brown Clay

$=$ 10YR 8/3 Very Pale Brown, Silty Clay

-

$[D=$ Construction Fill

Figure 5. Backhoe Trench 3. 


\section{Backhoe Trench 4}

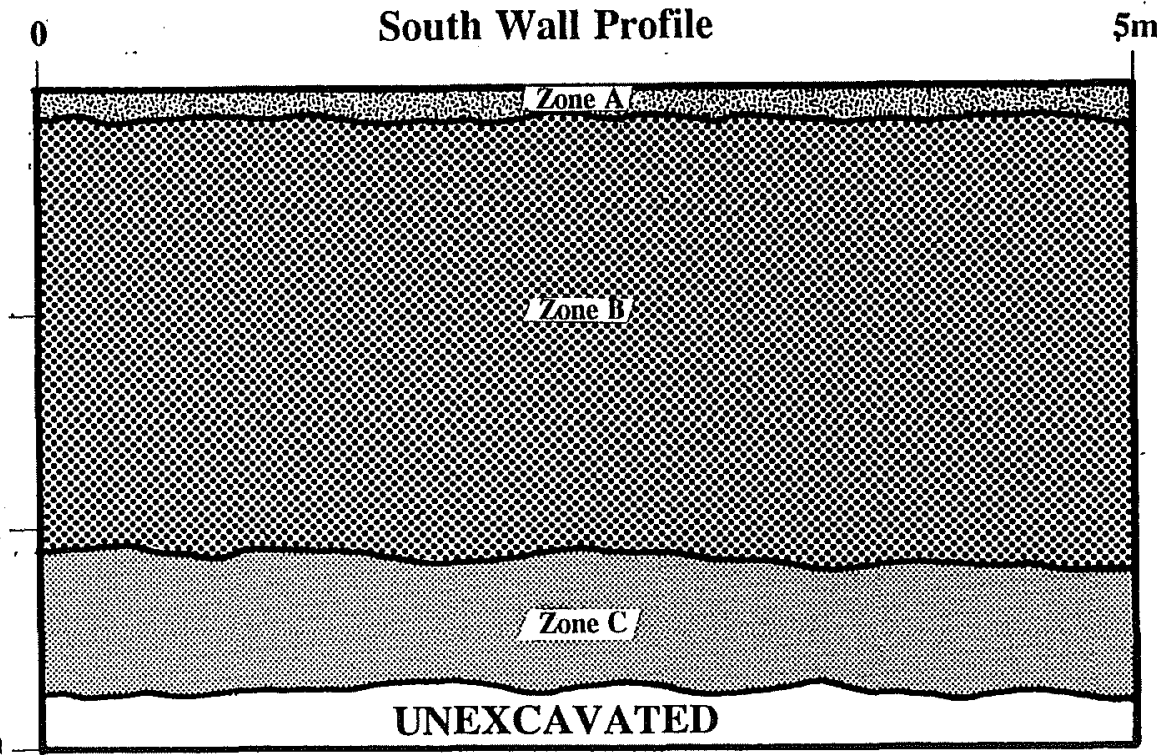

$5 \mathrm{~m}$

w $=$ 10YR 4/2 Dark Grayish Brown, Clay Loam \% $=10$ YR 3/2 Very Dark Grayish Brown Clay

\%: $=$ 10YR 6/3 Pale Brown Clay

$=$ 10YR 8/3 Very Pale Brown, Silty Clay

ZU = Construction Fil

$3 \mathbf{m}$

UNEXCAVATED

0

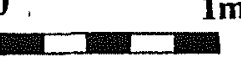

Figure 6. Backhoe Trench 4 


\section{RESULTS AND DISCUSSION}

Archival photographs and dam construction specifications revealed the project area had undergone limited alteration during the construction of the dam in 1948. Between 1948 and 1994 , the trees and other vegetation were allowed to grow to maturity. In preparation for constructing the concrete rolled spillway, the land was again cleared in 1994. Using a bulldozer and backhoe, construction crews pushed over the mature trees and pulled any remaining roots from the soil. Cavities left from the root extractions were bladed smooth, using the surrounding surface soil as fill. The pedestrian survey determined the site boundaries to be $70 \mathrm{~m}(\mathrm{n}-\mathrm{s}) \times 25 \mathrm{~m}$ (e-w). The surveyors also observed erosion downcutting which had washed artifacts downslope toward Medio Creek.

Examination of the four backhoe trenches revealed five distinct deposits separated either by changes in color, particle size, or structure. For field expedience and consistency, the distinct layers of deposits were designated "zones." A zone is considered to be a geologically neutral term acceptable for labeling sediment layers. Similar sediment layers receive the same zone designation; however these are not soil horizons (Bousman et al. 1988:39). Zones were defined using a standard Munsell soil color chart. Zone A was defined as a 10YR 4/2 dark grayish brown clay loam; Zone B, a 10 YR $3 / 2$ very dark grayish brown clay; Zone C, a 10YR 6/3 pale brown clay; Zone $D$, a 10YR $8 / 3$ very pale brown silty clay; and Zone $E$, construction fill.

The four backhoe trenches revealed a sequence of alluvial deposition, erosion, and surface stability. BHT 1 (Figure 3) contained well-stratified subsurface deposits: Zone A lay over Zone B, followed by Zone $\mathrm{C}$.

BHT 2 (Figure 4) was placed $5 \mathrm{~m}$ southeast of BHT 1. The irregular deposits in BHT 2 indicate the shifting of the Medio Creek channel. Underlying Zones A, B, and C, was Zone D; however, the silty clay was truncated from west to east by a second B zone. The west end of the trench was dug to $2.8 \mathrm{~m}, 0.8 \mathrm{~m}$ below the surface level of Medio Creek ( $3 \mathrm{~m}$ to the west). A third B deposit was discovered below Zone $D$.

BHT 3 was conspicuous for its absence of B and C zones between Zones A and D (Figure 5). This stratigraphy is most probably the result of fluvial scouring. The stratigraphy of BHT 4 (Figure 6) revealed that under the flat, $8-\mathrm{m}$ terrace surface a relatively deep $(2 \mathrm{~m}$ ) deposit of Zone B overlays the pale brown clay of Zone $C$.

BHTs 1 and 2 (Figure 2) also revealed a strata of construction fill (Zone $E$ ) across the surface, most probably because of their close proximity to the dam. Only one shovel test (I-9) contained cultural material. The profile of Trench 3 indicates that ST I-9 was placed in a refilled root cavity.

Three concentration areas of artifacts on the site surface consisted of 8 to 10 artifacts each. Artifacts observed on the site surface consisted of 1 quarry blank (large, thin biface [Turner and Hester 1985:24-26]), 1 nondiagnostic snapped biface, approximately 75 secondary flakes, and a sparse scatter of golf ball-size firecracked rock. The distribution of the firecracked rock formed no distinct spatial pattern, indicating it may be a hearth disturbed by land-clearing activities.

\section{CONCLUSIONS AND RECOMMENDATIONS}

Site 41BX1131 has been severely impacted by previous construction activities. Surface disturbance has displaced any appearance of artifact integrity. Systematic shovel testing of the site indicated no evidence of intact subsurface cultural deposits. Because of the absence of in situ archaeological deposits, the site is of little or no archaeological significance, and therefore ineligible for inclusion in the National Register of Historic Places. We recommend that the project be allowed to proceed without further consultation with the COE-FWD or the Texas SHPO. 


\section{REFERENCES CITED}

Black, S. L.

1989 South Texas Plains. In From the Gulf to the Rio Grande: Human Adaptation in Central, South, and Lower Pecos Texas, edited by T. R. Hester, S. L. Black, D. G. Steele, B. W. Olive, A. A. Fox, K. J. Reinhard, and L. C. Bement, pp 39-62. Arkansas Archaeological Survey Research Series \#33, Fayetteville.

Bousman, C. B., M. B. Collins, and T. K. Perttula

1988 Quaternary Geomorphology at Cooper Basin. A Framework for Archaeological Inquiry, Delta and Hopkins Counties, Texas. Reports of Investigations, Number 55. Prewitt and Associates, Austin.

Bureau of Economic Geology

1974 Geologic Atlas of Texas, San Antonio Sheet. University of Texas, Austin.

Judson, S. and M. E. Kauffman

1990 Physical Geology. Prentice Hall, Englewood Cliffs, New Jersey.

Guderjan, T. H., B. Meissner, B. Baker, C. K. Chandler, S. Kennedy, D. McReynolds, H. R. Smith, F. Ward, J. Watts, and J. Zapata

1993 The Medina Valley Project and the 1992 STAA-ITC Field School. La Tierra 20(1):12-26.

McGraw, A. J. and K. Hindes

1987 Chipped Stone and Adobe. Archaeological Survey Report, No. 163, Center for Archaeological Research, The University of Texas at San Antonio.

Nickels, D. L., D. W. Pease, and R. Rector (assemblers)

1995 Site Records for the Lackland Air Force Base Survey Project 1994-1995. Volumes I and II. Center for Archaeological Research, The University of Texas at San Antonio.

Turner, S. E. and T. R. Hester

1985 A Field Guide to Stone Artifacts of Texas Indians. Gulf Publishing, Houston.

Taylor, F. B., R. B. Hailey, and D. L. Richmond

1962 Soil Survey of Bexar County, Texas. Soil Conservation Society, U.S. Department of Agriculture, Washington, D.C. 
